\title{
KELAYAKAN FINANSIAL USAHA TANI DAN PERSEPSI PETANI TERHADAP KEBIJAKAN KENAIKAN TARIF CUKAI HASIL TEMBAKAU (Studi Kasus di Kecamatan Suralaga Kabupaten Lombok Timur)
}

\author{
Dudi Septiadi ${ }^{*}$, Rosmilawati ${ }^{1}$, Abdullah Usman' 'Asri Hidayati ${ }^{1}$ \\ ${ }^{1}$ Program Studi Agribisnis, Fakultas Pertanian, Universitas Mataram, Indonesia \\ *Co-author: dudi@unram.ac.id
}

\section{Article Information}

History:

Received: 02-09-2021

Accepted: 28-10-2021

\section{Keywords:}

Cigarette taxes

Farmer's perspective

Income analysis

Tobacco farming

\section{A. LATAR BELAKANG}

Awal tahun 2019 pemerintah menetapkan kebijakan peningkatan tarif cukai hasil tembakau. Keputusan pemerintah menetapkan bahwa terdapat peningkatan tarif cukai produk hasil tembakau sebesar 23 persen. Menteri keuangan Republik Indonesia telah

\begin{abstract}
Abstrak: Tembakau merupakan komoditas strategis nasional yang memiliki kontribusi cukup besar dalam penerimaan negara dan ketersediaan lapangan pekerjaan. Tujuan penelitian ini adalah untuk menganalisis pendapatan usahatani tembakau dan menganalisis persepsi petani terkait kebijakan kenaikan tarif cukai hasil tembakau/pajak rokok. Metode penelitian yang digunakan adalah analisis kualitatif dengan pendekatan analisis deskriptif. Penelitian dilakukan di Kecamatan Suralaga, Kabupaten Lombok Timur. Kecamatan Suralaga dipilih karena menjadi kecamatan yang banyak membudidayakan komoditas tembakau. Responden yang dipakai sebanyak 30 petani. Sejumlah 15 petani bertempat tinggal di Desa Bagik Payung, sebagian lagi sebanyak 15 petani bertempat tinggal di Desa Waringin. Kedua desa tersebut banyak petani tembakau dan merupakan daerah yang terletak di Kecamatan Suralaga, Kabupaten Lombok Timur. Hasil analisis kelayakan finansial menyatakan usahatani tembakau layak untuk diusahakan, karena berdasarkan analisis usahatani mengalami pendapatan (keuntungan) sebesar Rp. 8.045.942/hektar/musim tanam dengan nilai tingkat kelayakan usahatani sebesar 1,70>1 (kategori layak diusahakan). Sebagian besar petani memiliki persepsi bahwa kebijakan kenaikan cukai tembakau/pajak rokok bertujuan membantu perekonomian nasional melalui peningkatan penerimaan Negara, bukan untuk mengendalikan tingkat konsumsi rokok. Pemerintah daerah/pusat belum pernah memberikan sosialisasi kenaikan cukai tembakau/rokok. Disamping itu, petani juga beranggapan bahwa pemerintah belum pernah memberikan bantuan/kompensasi kepada petani pasca kebijakan kenaikan cukai tembakau/rokok. Kenaikan cukai rokok tidak berdampak langsung pada penurunan kondisi ekonomi (pendapatan) petani, faktor yang paling berpengaruh langsung pada pendapatan petani adalah kondisi cuaca yang tidak menentu (perubahan iklim) dan penentuan grade harga jual dari hasil panen tembakau yang kurang transparan.
\end{abstract}

\begin{abstract}
Tobacco is a national strategic commodity that contributes to state revenues and employment. The purpose of this research is to analyze tobacco farming income and to analyze farmers' perceptions regarding the policy of increasing excise tariffs on processed tobacco/cigarette taxes. The research method used is qualitative analysis with a descriptive analysis approach. The research was conducted in Suralaga District, East Lombok Regency. Suralaga sub-district was chosen because it is a sub-district that mostly cultivates tobacco commodities. Respondents used in this study were 30 respondent farmers. 15 farmers live in Bagik Payung Village, some 15 farmers live in Waringin Village. Both villages are tobacco farmers and are located in Suralaga District, East Lombok Regency. The results showed that tobacco farming in East Lombok Regency was declared feasible because based on the analysis, the farming experienced an income (profit) of Rp. 8,045,942/hectare/planting season with a farming feasibility level of 1.70>1 (feasible category). Most farmers have the perception that the policy of increasing tobacco excise/cigarette tax aims to help the national economy through increasing state revenues, not to control the level of cigarette consumption. The local/central government has never socialized the increase in tobacco/cigarette excise. In addition, farmers also assume that the government has never provided assistance or compensation to farmers after the policy of increasing tobacco/cigarette excise. The increase in cigarette excise does not have a direct impact on the decline in the economic condition of farmers. The factors that have the most direct influence on farmers' income are uncertain weather conditions (climate change) and the determination of the selling price grade of tobacco harvests which is less transparent.
\end{abstract}

menerbitkann Permenkeu nomor 156/PMK.010/2018 (PMK 156/2018). Peraturan tersebut mengatur perihal perubahan tarif cukai hasil tembakau. Kebijakan tersebut berlaku terhitung 1 januari 2019 (Kemenkeu, 2018). Ditetapkannya kenaikan tarif cukai diharapkan mampu menjadi stimulus pertumbuhan ekonomi 
melalui penerimaan Negara. Kebijakan ini diambil di tengah situasi APBN yang sedang defisit. Alasan esensial yang tak kalah penting dari kenaikan cukai rokok adalah isu kesehatan, dimana peningkatan kenaikan cukai rokok ditetapkan sebagai upaya pengendalian konsumsi rokok. Argument ini didukung hasil penelitian (Romli et al., 2019) yang menjelaskan bahwa upaya paling efektif dari kebijakan pengendalian konsumsi rokok sebagai produk hasil tembakau adalah dengan menaikan tarif cukainya. Apabila kenaikan cukai rokok ditetapkan, maka diduga perusahaan akan merespon dengan menaikan harga jual rokok. Penetapan harga jual rokok menjadi lebih mahal inilah yang mendorong konsumen mengurangi tingkat konsumsinya.

Di sisi lain kebijakan kenaikan tarif cukai atas produk hasil tembakau memiliki dampak yang cukup besar pada ekosistem industri hasil olahan tembakau, baik di sektor hulu maupun hilir. Dari sisi hulu, petani tembakau sebagai pelaku utama budidaya tembakau tidak memiliki pilihan lain selain terus berproduksi. Meskipun pasca kenaikan tarif cukai hasil tembakau berdampak pada tingkat penerimaan petani. Hal ini dibuktikan dengan adanya penurunan harga beli hasil panen petani tembakau yang ditetapkan pengepul atau perusahaan mitra. Harga tembakau turun Perusahaan yang bermitra dengan petani tembakau mematok harga tembakau kering berkisar antara Rp 15.00o sampai Rp 50.000 per kilogram. Nilai ini mengalami penurunan 50 persen dibanding harga beli tahun 2019 sebelum kenaikan tarif cukai (Farasonalia, 2019). Penurunan ini tentunya menurunkan tingkat penerimaan petani yang memiliki dampak langsung pada tingkat pendapatan petani. Penurunan pendapatan mengancam kelayakan usahatani di masa akan datang(Indah et al., 2020). Dibutuhkan peran pemerintah dalam mengelola kebijakan perdagangan, agar harga jual tidak fluktuatif, dan petani tidak mengalami kerugian (Sari, Nofialdi and Putri, 2020).

Di sisi lain, biaya produksi usahatani tembakau relatif tetap. Kebijakan ini cenderung menurunkan tingkat kesejahteraan petani tembakau. Dari sisi hilir, sektor industri produksi olahan tembakau yang paling terdampak tentunya adalah industri rokok. Sebagian besar produk olahan tembakau dijadikan produk rokok. Peningkatan cukai ini secara otomatis akan menjadi beban bagi perusahaan karena harus membayar pajak cukai rokok lebih besar dari sebelumnya. Berdasarkan beberapa riset yang telah ada, peningkatan tarif cukai umumnya akan berdampak pada penurunan pendapatan petani dibuktikan dengan adanya penurunan surplus ekonomi petani tembakau (Suprihanti et al., 2019).

Provinsi Nusa Tenggara Barat (NTB) merupakan provinsi penghasil tembakau dengan pangsa yang cukup besar. Selama kurun waktu 2016-2020 produksi rerata di Provinsi NTB menyumbang 25 persen produksi tembakau nasional. Kabupaten Lombok Timur menjadi wilayah yang memiliki luas areal panen dan kontribusi produksi tembakau terbesar dibanding wilayah lain di Provinsi NTB. Temuan ini menunjukkan komoditas tembakau di NTB khususnya Kabupaten Lombok Timur berperan penting dalam pemenuhan permintaan tembakau nasional. Akan tetapi, berdasarkan studi awal yang dilakukan peneliti, masih banyak petani yang tidak mengetahui adanya kenaikan tarif cukai hasil tembakau. Tercatat dari 30 petani yang peneliti wawancarai, hanya ada 1 petani yang mengetahui adanya kenaikan tarif cukai hasil tembakau pada tahun 2020 (Data primer, 2021), petani belum mengetahui kelayakan dan keberlanjutan usahatani tembakau pasca kebijakan kenaikan cukai hasil tembakau. Analisis kelayakan finansial perlu mendapatkan perhatian serius dalam kebijakan pembangunan pertanian (Sudrajat, 2020). Hal tersebut dikarenakan analisis kelayakan finansial dapat memberikan informasi terkait tingkat kelayakan finansial dari usahatani (Fauziyah, Suhaendah and Manurung, 2020). Berdasarkan hasil analisis tersebut bisa diketahui suatu usahatani layak atau tidak untuk diusahakan (Pertiwi and Prastya, 2020). Berdasarkan penjelasan diatas, maka penulis memiliki ketertarikan dalam menginvestigasi lebih lanjut perihal 1) kelayakan finansial usahatani tembakau di Kecamatan Suralaga, Kabupaten Lombok Timur; dan 2) persepsi petani tembakau perihal kebijakan kenaikan tarif cukai hasil tembakau.

\section{B. METODE PENELITIAN}

Penelitian ini dilakukan di Kecamatan Suralaga, Kabupaten Lombok Timur yang menjalankan usahatani tembakau. Kecamatan Suralaga dipilih karena daerah tersebut terdapat petani yang membudidayakan tembakau yang cukup banyak di Kabupaten Lombok Timur. Di Kecamatan tersebut dipilih dua desa secara purposive sampling yang memiliki lahan tembakau yang luas, yakni Desa Waringin dan Desa Bagik Payung. Pada penelitian ini menggunakan 30 responden petani yang menjalankan usahatani tembakau rajangan. Jumlah sampel yang digunakan merupakan kriteria minimal sampel yang masih memungkinkan untuk penelitian (Sugiyono, 2011). Peneliti menggunakan kriteria minimum karena pada saat penelitian kondisi penyebaran Covid-19 sangat tinggi di Pulau Lombok, sehingga pada saat turun ke lapangan hanya menemui 30 responden. Dimana 15 responden diantaranya merupakan petani tembakau yang berasal dari Desa Waringin, 15 responden berikutnya berasal dari Desa Bagik Payung. Penelitian dilakukan dari bulan Juli Agustus 2021.

Metode penelitian menggunakan pendekatan kualitatif-deskriptif. Penelitian kualitatif-deskriptif merupakan prosedur penelitian yang mengumpulkan 
data tertulis terkait perilaku yang diamati kemudian di deskripsikan kemudian ditarik kesimpulan (Creswell, 2002). Prosedur penelitian deskriptif dipilih dengan harapan hasil analisis yang dilakukan dapat dipaparkan secara jelas dan mudah dipahami.

Untuk menganalisis tingkat pendapatan petani, dalam penelitian ini menggunakan analisis pendapatan (Septiadi, Suparyana and FR, 2020). Rumusnya adalah sebagai berikut;

$$
\pi=\mathrm{TR}-\mathrm{TC} \text {.................. (1) }
$$

$\mathrm{TR}=$ penerimaan petani tembakau $(\mathrm{Rp} / \mathrm{Ha} / \mathrm{MT})$

$\mathrm{TC}=$ biaya produksi petani tembakau $(\mathrm{Rp} / \mathrm{Ha} / \mathrm{MT})$

$\pi=$ pendapatan (keuntungan) petani tembakau (Rp/ Ha/MT)

Analisis kelayakan finansial usahatani dipakai dalam menginvestigasi kelayakan suatu usahatani, persamaannya dijabarkan berikut ini (Sari et al, 2020).

$$
B / C \text { Ratio }=\frac{\text { Total Penerimaan }}{\text { Total Biaya Produksi }}=\frac{T R}{T C}
$$

Adapun kriteria yang digunakan adalah sebagai berikut :

1. Apabila nilai $\mathrm{B} / \mathrm{C}$ Ratio $>1$ berarti Usahatani tembakau menguntungkan dan layak untuk diusahakan.

2. Apabila nilai $\mathrm{B} / \mathrm{C}$ Ratio $<1$ berarti Usahatani tembakau tidak menguntungkan dan tidak layak untuk diusahakan.

3. Apabila nilai $\mathrm{B} / \mathrm{C}$ Ratio $=1$ berarti Usahatani tembakau Break Even Point.

Persepsi petani dianalisis dengan pendekatan survey. Instrumen penelitian yang digunakan berupa kuesioner, dimana aspek yang dipersepsikan dan dinilai dalam penelitian ini adalah: (a) persepsi terhadap manfaat kenaikan cukai hasil tembakau/pajak rokok; (b) persepsi terhadap sosialisasi pemerintah daerah/pusat terkait kenaikan cukai hasil tembakau/pajak rokok; (c) persepsi terhadap program pemerintah terkait kebijakan kompensasi bagi petani pasca kenaikan cukai hasil tembakau/pajak rokok; (d) persepsi terhadap kondisi ekonomi petani pasca kenaikan cukai hasil tembakau/pajak rokok. Data yang telah dikumpulkan kemudian dilakukan analisis dengan pendekatan analisis deskriptif. Analisis dilakukan berbasiskan tabulasi, kemudian diolah dan disajikan dalam bentuk tabel.

\section{HASIL DAN PEMBAHASAN}

\section{Karakteristik Petani Tembakau di Kabupaten Lombok Timur}

Berdasarkan Tabel 1 dapat diketahui bahwa rerata usia petani adalah 48 tahun, artinya petani tembakau di Lombok Timur masih dalam usia produksi. Kategori usia lahir berada pada kisaran 1564 tahun (BPS, 2019). Temuan ini menegaskan bahwa pekerjaan di sektor pertanian masih ada di tempat-tempat di mana budidaya tembakau dikelola oleh masyarakat pada usia produksi.

Tabel 1.

Identitas Petani Sampel

\begin{tabular}{lll} 
No & Identitas Responden & Keterangan \\
\hline 1. & Jumlah petani (orang) & 30 \\
2 & Rerata Umur (tahun) & 48 \\
3. & Rerata Pendidikan Formal (tahun) & 6 \\
4. & Rerata jumlah anggota keluarga (orang) & 3 \\
5. & Rerata pengalaman usahatani (tahun) & $\mathbf{2 2}$ \\
6. & Rerata luas lahan Tembakau (are) & $\mathbf{1 2}$ \\
\hline
\end{tabular}

Sumber: data primer diolah (2021)

Rerata petani tembakau telah menempuh pendidikan hingga lulus sekolah dasar (6 tahun). Temuan penting yang menunjukkan petani memilki tingkat pendidikan yang rendah. Padahal menurut Herminingsih dan Rokhani (2014) pendidikan formal berpengaruh positif dan signifikan terhadap perilaku petani. Semakin tinggi tingkat pendidikan formal petani, semakin berani dalam mengambil resiko. Rendahnya tingkat pendidikan yang ditempuh petani tembakau diduga menjadi pemicu sebagian besar petani yang berperilaku menghindari resiko dalam menjalankan kegiatan usahatani. Pendidikan merupakan faktor penting yang mempengaruhi pengambilan keputusan petani untuk beradaptasi dengan perubahan lingkungan. Penelitian yang dilakukan Anley et al. (2007) menyimpulkan bahwa peningkatan pendidikan dan lapangan kerja adalah kunci untuk mendorong partisipasi petani dalam adaptasi dan pengelolaan sumber daya alam yang inovatif. Dengan demikian, penting sekali bagi pihak yang berkepentingan dalam sektor pertanian dalam uapayanya meningkatkan pendidikan formal para petani sebagai manifestasi dari peningkatan sumberdaya manusia di sektor pertanian (Kasri, 2011). Selain pendidikan, aspek yang perlu digencarkan adalah pelatihan budidaya tembakau. Menurut hasil penelitian Herminingsih dan Rokhani (2014) pelaksanaan pelatihan pada petani merupaka salah satu faktor yang memiliki dampak positif pada pengambilan resiko usahatani tembakau. Pasca pelatihan petani lebih berani berinovasi, sehingga memiliki peluang untuk meningkatkan produksi tembakau. Ketersediaan informasi melalui penyuluhan dan pelatihan budidaya pertanian mempermudah pengambilan keputusan komparatif bagi petani dalam menjalankan usahatani.

Rerata jumlah anggota keluarga para petani tembakau sebanyak tiga orang. Akan tetapi tidak semua anggota keluarga bersedia bekerja di sektor pertanian. Masih ditemukan sebagian keturunan petani tidak mau berpartisipasi dan bekerja sebagai petani. Sebagian keturunan petani memilih bekerja di sektor non pertanian. Temuan penelitian ini sesuai dengan penelitian Wehantouw et al. (2018) yang mengungkapkan bahwa salah satu faktor yang memotivasi keturunan petani untuk memilih karir di sektor non pertanian adalah upah di sektor non pertanian lebih tinggi dari upah di sektor pertanian. Hal ini juga menguatnya stereotip di masyarakat bahwa pekerjaan dengan nilai sosial tinggi adalah mereka yang bekerja di sektor non pertanian, seperti industri, pendidikan, dan perbankan. 
Pengalaman yang dimiliki petani dalam usahatani tembakau cukup baik. Berdasarkan informasi yang disajikan pada Tabel 1 menunjukkan rerata petani telah menanam tembakau selama 22 tahun. Cukup baiknya pengalaman petani tembakau di Kabupaten Lombok Timur merupakan pertanda positif bagi budidaya tembakau di Kabupaten Lombok Timur. Hasil penelitian Amalina et al. (2020) memperkuat temuan ini, dimana petani dapat belajar dari pengalamannya melakukan usahatani tembakau, sehingga petani dapat mengatasi berbagai resiko dari kegagalan usaha taninya. Hal ini sejalan dengan temuan penelitian Nyanga et al. (2011) yang mengungkapkan petani dengan kelebihan pada aspek pengalaman memiliki keunggulan dalam hal pengetahuan dan informasi, sehingga memiliki langkah mitigasi dari kendala yang mungkin akan dihadapi. Hal ini juga berarti bahwa pengalaman bertani dapat meningkatkan manajemen pertanian mereka dan memungkinkan petani menggunakan bahan produksi secara lebih efektif (Lutfi and Baladina, 2018).

Luas areal panen (lahan) petani tembakau dalam penelitian ini rerata seluas 12 are atau setara dengan 0,12 Hektar. Nilai ini cukup kecil dibanding rerata kepemilikan lahan petani di Indonesia, yaitu seluas 0,4 hektar/petani (Septiadi, 2016).

\section{Analisis Pendapatan Usahatani Tembakau}

\section{a. Biaya Produksi Usahatani}

Pada penelitian ini biaya produksi merupakan seluruh biaya yang dikeluarkan petani dalam kegiatan produksi usahatani tembakau. Biaya produksi dinyatakan dalam satuan rupiah/Hektar. Komponen biaya yang termasuk dalam biaya produksi pada usahatani tembakau antara lain :

1. Biaya sarana produksi (saprodi) ditentukan dengan mengalikan harga satuan input saprodi dengan jumlah saprodi aktual yang digunakan. Biaya sarana produksi di antaranya adalah penggunaan benih, pupuk urea dan pestisida cair.

2. Biaya tenaga kerja adalah total biaya upah yang dihitung dengan jumlah pekerja dan lama hari kerja atau jam kerja dikalikan upah hari kerja.

Tabel 2.

Rerata Biaya Produksi pada Usahatani Tembakau di Kabupaten Lombok Timur

\begin{tabular}{llrr}
\hline No & Uraian & $\begin{array}{c}\text { Biaya Per } \\
\text { Hektar (Rp) }\end{array}$ & \% \\
\hline 1 & Benih & 934.348 & 8 \\
2 & Pupuk Urea & 3.064 .052 & 27 \\
3 & Pestisida Cair & 913.246 & 8 \\
4 & Tenaga Kerja & 6.529 .887 & 52 \\
\hline & Jumlah & 11.441 .533 & 100 \\
\hline
\end{tabular}

Sumber: data primer diolah (2021)

Berdasarkan informasi yang disajikan pada Tabel 2 dapat dijelaskan bahwa proporsi paling besar untuk biaya produksi usahatani tembakaurerata per hektar adalah biaya tenaga kerja dengan persentase sebanyak 52 persen, dengan nominal sebesar Rp. 6.529.887/Ha. Tenaga kerja yang banyak digunakan berasal dari luar keluarga. Kegiatan usahatani yang banyak menyerap tenaga kerja dari luar keluarga diantaranya adalah kegiatan persiapan dan pengolahan lahan, penanaman, pemeliharaan, penyiangan, pemupukan, penyemprotan, panen, dan pasca panen. Komponen pengeluaran terbesar kedua untuk biaya produksi adalah biaya pembelian pupuk urea dengan kontribusi sebesar 27 persen dengan nilai pengeluaran sebesar Rp. 3.064.052/Ha. Selebihnya Pengeluaran untuk benih dan pestisida cair masing-masing berkontribusi sebesar 8 persen saja.

\section{b. Penerimaan}

Penerimaan usahatani tembakau dalam penelitian ini merupakan rerata penerimaan usahatani tembakau per hektar. Rerata penerimaan usahatani tembakau ditentukan dari perkalian antara nilai rerata output produksi tembakau per hektar dengan rerata harga tembakau (Rupiah/kwintal). Penjelasan lebih detail ditunjukkan pada Tabel 3 .

\section{Tabel 3.}

Rerata penerimaan usahatani tembakau di Kabupaten Lombok Timur

\begin{tabular}{llr}
\hline No & Item & Keterangan \\
\hline 1 & Rerata Produksi Tembakau/Ha & 75 Kwintal \\
2 & Rerata Harga Tembakau/Kwintal & Rp. 259.833 \\
\hline & Rerata Penerimaan Usahatani & Rp. 19.487 .475 \\
\hline
\end{tabular}

Sumber: data primer diolah (2021)

Berdasarkan Tabel 3 dapat diketahui bahwa rerata produksi usahatani tembakau adalah sebanyak 75 kwintal per hektar. Sedangkan rerata harga tembakau rajangan sebesar Rp. 259.833 per hektar. Dengan demikian rerata penerimaan usahatani tembakau sebesar Rp. 19.487.475 per hektar. Nilai ini sejalan dengan hasil penelitian (Ahmadi, 2016) yang mengungkapkan bahwa penerimaan usahatani tembakau rakyat di Kabupaten Lombok Timur sebesar Rp. 19.403.150 per hektar. Nilai penerimaan yang tidak jauh berbeda ini dikarenakan lokasi penelitian berada di kabupaten yang sama, hanya berbeda tempat tinggal sampel (desa dan kecamatan). Sehingga memiliki kemiripan dalam hal karakteristik responden. Sedangkan hasil penelitian Amalina et al. (2020) menunjukkan besaran omset usahatani tembakau di daerah Eromoko, Kabupaten Wonogiri nilainya adalah Rp. 41.468.145 per hektar.

\section{c. Pendapatan}

Pendapatan usahatani tembakau merupakan nilai rata- rata penerimaan usahatani dikurangi rerata biaya produksi usahatani.

Tabel 4.

Rerata pendapatan usahatani tembakau di Kabupaten Lombok Timur

\begin{tabular}{llr}
\hline No & Rerata & Per Hektar (Rp) \\
\hline 1 & Penerimaan usahatani & 19.487 .475 \\
2 & Biaya produksi usahatani & 11.441 .533 \\
\hline & Rerata pendapatan usahatani & 8.045 .942 \\
\hline Sumber: data primer diolah $(2021)$
\end{tabular}

Sumber: data primer diolah (2021) 
Berdasarkan informasi yang disajikan pada Tabel 4, penerimaan usahatani tembakau rerata per hektar adalah sebanyak Rp. 19.487.475.Sedangkan biaya produksi usahatani tembakau rerata per hektar sebesar Rp. 11.441.533. Dengan demikian pendapatan usahatani tembakau rerata per hektar senilai Rp. 8.045.942. Nilai tersebut berkesesuaian dengan hasil penelitian (Nur and Salim, 2014) yang mengungkapkan bahwa pendapatan usahatani tembakau sebesar Rp. 12.000.00o per hektar. Sedangkan hasil penelitian Estariza et al. (2013) mengungkapkan bahwa keuntungan yang dihasilkan petani tembakau di Kabupaten Lampung Timur sebesar Rp. 16.820.881,79 per hektar.

\section{d. Kelayakan Finansial Usahatani Tembakau}

Tingkat kelayakan finansial usahatani tembakau merupakan nilai rerata total penerimaan usahatani dibagi dengan rerata total biaya produksi usahatani pada penggunaan lahan 1 hektar.

Tabel 5 .

Tingkat kelayakan usahatani tembakau di Kabupaten Lombok Timur

\begin{tabular}{llr}
\hline No & Rerata & \multicolumn{1}{l}{$\begin{array}{l}\text { Per Hektar } \\
\text { (Rp) }\end{array}$} \\
\hline 1 & Penerimaan usahatani & 19.487 .475 \\
2 & Biaya produksi usahatani & 11.441 .533 \\
\hline & Tingkat kelayakan finansial & 1,70 \\
\hline
\end{tabular}

Sumber: data primer diolah (2021)

Berdasarkan Tabel 5 dapat diketahui bahwa rerata penerimaan usahatani tembakau adalah sebanyak Rp. 19.487.475 per hektar. Sedangkan rerata biaya produksi usahatani tembakau sebesar Rp. 11.441.533 per hektar, sehingga tingkat kelayakan usahatani tembakau di Kabupaten Lombok Timur adalah sebesar 1,70. Dengan demikian usahatani di Kabupaten Lombok Timur dinyatakan layak untuk dijalankan. Hal ini sejalan dengan penelitian Estariza et al. (2013) yang menyatakan bahwa usahatani tembakau di Kabupaten Lampung Timur layak untuk dijalankan dengan nilai tingkat kelayakan 95 inancial sebesar 1,58 (layak diusahakan).

\section{Analisis Persepsi Petani Tembakau}

\section{a. Persepsi terhadap manfaat kenaikan cukai tembakau}

Dasar pertimbangan pemerintah dalam menaikkan tingkat cukai/pajak hasil olahan tembakau adalah selain untuk meningkatkan sumber pendapatan negara melalui pajak, kebijakan ini juga untuk menekan laju konsumsi rokok yang cukup tinggi (Suprihatni et al, 2019). Tingginya konsumsi rokok dipandang memiliki dampak negatif dari aspek kesehatan dan biaya sosialnya cukup tinggi (Wandita, 2020). Persepsi petani terhadap manfaat kenaikan cukai tembakau dijelaskan pada Tabel 5 .
Tabel 6.

Persepsi terhadap manfaat kenaikan cukai tembakau

\begin{tabular}{clcc}
\hline No & Pernyataan & Frekuensi & persentase \\
\hline 1. & $\begin{array}{l}\text { Kebijakan kenaikan cukai } \\
\text { tembakau/pajak rokok } \\
\text { bertujuan membantu }\end{array}$ & 21 & \\
& $\begin{array}{l}\text { perekonomian nasional } \\
\text { Kebijakan kenaikan cukai } \\
\text { tembakau/pajak rokok }\end{array}$ & 9 & \\
& untuk mengendalikan \\
tingkat konsumsi rokok & & $30 \%$ \\
\hline
\end{tabular}

Sumber: data primer diolah (2021)

Pada penelitian ini telah dilakukan survey untuk melihat persepsi petani terhadap kecenderungan dua alasan penetapan kebijakan tersebut. Hasil survey menunjukkan bahwa 70 persen petani memiliki persepsi bahwa kebijakan kenaikan cukai tembakau/pajak rokok adalah untuk membantu perekonomian nasional. Apalagi pasca pandemi covid19, APBN terus mengalami defisit, sehingga pemerintah terus mencari alternatif sumber penerimaan negara. Hasil ini di dukung pernyataan Fadillah dan Kiswara (2012) bahwa kontribusi pajak cukai terhadap penerimaan negara cukup besar, sehingga kebijakan ini efektif dalam meningkatkan penerimaan negara.

\section{b. Persepsi terhadap sosialisasi pemerintah terkait kebijakan kenaikan cukai tembakau}

Sementara itu komunikasi publik oleh pemerintah perihal kebijakan kenaikan cukai hasil tembakau/pajak rokok menunjukkan angka yang mengejutkan.

\section{Tabel 7.}

Persepsi terkait sosialisasi pemerintah pada kebijakan kenaikan cukai tembakau

\begin{tabular}{llcc}
\hline No & Pernyataan & Frekuensi & persentase \\
\hline 1. & $\begin{array}{l}\text { Pemerintah daerah/pusat } \\
\text { memberikan sosialisasi } \\
\text { kenaikan cukai }\end{array}$ & 0 & \\
& tembakau/rokok & & \\
2. & $\begin{array}{l}\text { Pemerintah daerah/pusat } \\
\text { belum pernah memberikan } \\
\text { sosialisasi kenaikan cukai } \\
\text { tembakau/rokok }\end{array}$ & 100\% \\
& & \\
\hline Sumber: data primer diolah (2021)
\end{tabular}

Berdasarkan informasi yang disajikan pada Tabel 7 dapat diketahui bahwa semua responden menyatakan tidak pernah mendapat sosialisasi secara langsung dari pemerintah pusat maupun pemerintah daerah terkait kebijakan kenaikan cukai tembakau/pajak rokok. Temuan ini menjadi pesan penting bagi pemangku kebijakan agar memperbaiki komunikasi dengan petani sebagai stakeholder terbesar dari ekosistem pasar tembakau. Sosialisasi bisa dilakukan melalui pemerintah pusat maupun pemerintah daerah dengan mengoptimalkan peran penyuluh pertanian. 


\section{c. Persepsi petani terhadap kebijakan kompensasi pasca kenaikan cukai hasil tembakau}

Kebijakan kompensasi pasca penetapan kebijakan kenaikan cukai juga mendapat sorotan di penelitian ini. Dimana juga terdapat hasil yang mengejutkan. Berdasarkan Tabel 7 diketahui bahwa semua petani responden mengaku tidak pernah ada kebijakan kompensasi apapun pasca kebijakan kenaikan cukai rokok. Beberapa petani mengungkapkan pernah ada kebijakan bantuan dari pemerintah berupa mesin alat berat untuk Kelompok Tani. Tapi bantuan tersebut sudah terjadi sangat lama dan alat tersebut sudah tidak berfungsi. Sampai saat ini belum ada bantuan lagi, terlebih pasca kenaikan cukai dan kondisi pandemi Covid-19 yang membuat pengaruh cukup besar bagi perekonomian petani.

Tabel 8.

Persepsi petani terhadap kebijakan kompensasi pasca kenaikan cukai tembakau/rokok

\begin{tabular}{llcc}
\hline No & Pernyataan & Frekuensi & persentase \\
\hline 1. & $\begin{array}{l}\text { Pemerintah belum pernah } \\
\text { memberikan }\end{array}$ & 30 & $100 \%$ \\
bantuan/kompensasi & & \\
kepada petani pasca & kebijakan kenaikan cukai & & \\
tembakau/rokok & 0 & $0 \%$ \\
2. & $\begin{array}{l}\text { Pemerintah memberikan } \\
\text { bantuan/kompensasi } \\
\text { kepada petani pasca } \\
\text { kebijakan kenaikan cukai } \\
\text { tembakau/rokok. }\end{array}$ & & \\
\hline
\end{tabular}

Sumber: data primer diolah (2021)

\section{d. Persepsi dampak kebijakan kenaikan cukai terhadap kondisi ekonomi petani}

Terdapat temuan menarik berdasarkan informasi yang disajikan pada Tabel 8, dimana ternyata terdapat 40 persen responden yang menyatakan kenaikan cukai tembakau/rokok mengakibatkan pendapatan petani menurun, sedangkan persentase lebih besar menyatakan kenaikan cukai tembakau/rokok tidak berpengaruh terhadap pendapatan petani tembakau. Petani berpandangan naik turunnya pendapatan bukan di dominasi oleh faktor kenaikan cukai, tapi ada faktor lain.

\section{Tabel 9.}

Persepsi dampak kebijakan kenaikan cukai terhadap kondisi ekonomi petani

\begin{tabular}{llcc}
\hline No & Pernyataan & Frekuensi & persentase \\
\hline 1. & $\begin{array}{l}\text { Kenaikan cukai } \\
\text { tembakau/rokok } \\
\text { mengakibatkan pendapatan }\end{array}$ & 12 & $40 \%$ \\
petani menurun & & \\
2. & $\begin{array}{l}\text { Kenaikan cukai } \\
\text { tembakau/rokok tidak } \\
\text { berpengaruh terhadap } \\
\text { pendapatan petani tembakau. }\end{array}$ & 18 & $60 \%$ \\
\end{tabular}

Sumber: data primer diolah (2021)
Penelitian menghasilkan temuan penting terkait analisis masalah dilapangan yang berdampak pada produksi, sehingga berdampak langsung pada pendapatan dan kondisi ekonomi petani. Komponen alam yang paling berpengaruh terhadap penurunan produksi usahatani tembakau berdasarkan hasil pengamatan adalah faktor perubahan iklim/curah hujan. Tembakau merupakan kategori tanaman yang responsif (peka) pada kondisi usahataniyang mengalami kekurangan/kelebihan air. Kondisi tersebut relatif merugikan Petani di Kecamatan Suralaga karena memiliki sumber irigasi yang terbatas. Seringkali usahatani tembakau kekurangan air terutama pada saat awal pembenihan dan penanaman bibit yang membutuhkan cukup banyak air, sedangkan lokasi penelitian merupakan kawasan lahan kering. Sebaliknya terkadang ketika tanaman sudah besar, dan akan menjelang masa panen tembakau relatif tidak terlalu butuh banyak air, justru petani mengungkapkan tanamannya sering terkena hujan padahal sudah memasuki musim kemarau. Ketika terkena air hujan justru kualitas daun tembakau menurun. Perubahan iklim yang berdampak pada kesulitan petani menentukan masa tanam berdampak pada penurunan kualitas dan produksi tembakau basah. Hasil ini sejalan dengan temuan penelitian Nazam et al. (2014) yang mengungkapkan dampak langsung dari perubahan iklim terhadap usahatani tembakau adalah adanya pertumbuhan tanaman yang tidak normal dan penurunan produktivitas dan kualitas tanaman. Temuan ini penting untuk dijadikan rekomendasi kebijakan bagi pemerintah pusat maupun daerah dalam melakukan kebijakan kompensasi yang berorientasi pada pengadaan irigasi (sumber air). Khususnya ketika memasuki masa tanam yang membutuhkan cukup banyak air. Alternatif solusi bisa berupa penyediaan mesin pompa air atau pembuatan tempat penyimpanan air seperti bendungan atau waduk.

Selain masalah iklim, masalah yang memiliki dampak pada penurunan pendapatan dan kondisi ekonomi petani adalah kurang transparannya penentuan grade harga dari hasil panen tembakau. Pengepul/tengkulak masih mendominasi dalam penentuan grade dan harga jual hasil panen petani tembakau. Bagi petani yang minim akan akses informasi pasar seperti akses informasi penjualan ke perusahaan, maka pilihannya menjadi sangat terbatas. Petani tetap menjadikan tengkulak sebagai tempat menjual hasil panen tembakau. Petani tidak memiliki cukup bargaining dalam menentukan harga hasil panennya.

Berdasarkan pernyataan Ketua Kelompok Tani Fajar Menyingsing, untuk menambah sumber pendapatan, petani menerapkan sistem rotasi tanaman dan melakukan usahatani peternakan sapi. Lahan pertanian yang dimiliki petani di lokasi penelitian tidak hanya 
menanam tanaman tembakau saja. Petani tembakau juga biasanya menanam padi pada musim hujan dan tembakau yang dipadukan dengan tanaman cabai pada musim kemarau. Sebagian besar pendapatan petani justru dari budidaya tanaman cabai. Hal ini bertujuan untuk mendapatkan keuntungan tambahan.

\section{SIMPULAN DAN SARAN}

Usahatani tembakau di Kecamatan Suralaga Kabupaten Lombok Timur dinyatakan layak untuk diusahakan karena usahatani tembakau memperoleh pendapatan sebesar Rp. 8.045.942/hektar/musim tanam dan memiliki nilai tingkat kelayakan finansial sebesar 1,70 .

Sebagian besar petani memiliki persepsi bahwa kebijakan kenaikan cukai tembakau/pajak rokok bertujuan membantu perekonomian nasional melalui peningkatan penerimaan negara. Hanya sebagian kecil petani yang menganggap kebijakan kenaikan cukai tembakau/pajak rokok untuk mengendalikan tingkat konsumsi rokok. Pemerintah daerah/pusat belum pernah memberikan sosialisasi kenaikan cukai tembakau/rokok. Disamping itu, petani juga beranggapan bahwa pemerintah belum pernah memberikan bantuan/kompensasi kepada petani pasca kebijakan kenaikan cukai tembakau/rokok.

Kenaikan cukai rokok tidak berdampak langsung pada penurunan kondisi ekonomi petani, faktor yang paling berpengaruh langsung pada pendapatan petani adalah kondisi cuaca yang tidak menentu (perubahan iklim) dan penentuan grade harga jual dari hasil panen tembakau yang kurang transparan.

Disarankan untuk penelitian selanjutnya agar menggunakan sampel yang lebih besar agar memperoleh hasil penelitian yang lebih baik.

\section{UCAPAN TERIMA KASIH}

Penulis mengucapkan terima kasih kepada Rektor Universitas Mataram, Ketua LPPM dan Dekan Fakultas Pertanian Unram atas pendanaan penelitian melalui dana PNBP Universitas Mataram tahun 2021.

\section{DAFTAR RUJUKAN}

Amalina, A. N., Darsono and Farichani, M. (2020) 'Analisis Efisiensi Penggunaan Input Produksi Pada Usahatani Tembakau di Kecamatan Eromoko, Kabupaten Wonogiri', AGRISTA, 8(3), pp. 110-121.

Anley, Y., Bogale, A. and Haile-Gabriel, A. (2007) 'Adoption decision and use intensity of soil and water conservation measures by smallholder subsistence farmers in Dedo District, Western Ethiopia', Land Degradation \& Development, 18(3), pp. 289-302. doi: 10.1002/ldr.775.

BPS (2019) Data Sosial dan Kependudukan Indonesia. Jakarta. Available at: https://www.bps.go.id/subject/12/kependudukan.html.

Creswell, J. (2002) Educational research: Planning, conducting, and evaluating quantitative (Fourth;
Matthew Buchholtz, ed.). Boston, USA: Pearson.

Estariza, E., Prasmatiwi, F. E. and Santoso, H. (2013) 'Efisiensi Produksi Dan Pendapatan Usahatani Tembakau Di Kabupaten Lampung Timur', Jiia, 1(3), pp. 264-270.

Fadillah, R. and Kiswara, E. (2012) 'Pengaruh Pengenaan Pajak Pertambahan Nilai Dan Cukai Rokok Terhadap Skema Finansial Produk Rokok', Diponegoro Journal of Accounting, 1(1), pp. 1-12.

Farasonalia, R. (2019) 'Tarif Cukai Rokok Naik, Nasib Petani Tembakau Semakin Terpuruk'. Semarang: Kompas.

Fauziyah, E., Suhaendah, E. and Manurung, G. S. (2020) 'Farmer's socio-economic characteristics and financial feasibility analysis of three pepper (Piper nigrum L.) farming patterns in Southeast Sulawesi', IOP Conference Series: Earth and Environmental Science, 533(1). doi: 10.1088/1755-1315/533/1/012021.

Herminingsih, H. and Rokhani (2014) 'Pengaruh perubahan iklim terhadap perilaku petani tembakau di kabupaten jember', jurnal matematika, Saint, Teknologi, 15(1), pp. $42-51$.

Indah, P. N. et al. (2020) 'Financial Feasibility Analysis and Cocoa Marketing Margin in Kare Village, Kare District, Madiun', IOP Conference Series: Earth and Environmental Science, pp. 149-160.

Kasri, R. A. (2011) 'Time series evidence on education and economic growth in Indonesia', Economic Journal of Emerging Markets, 3(2), pp. 109-123.

Kemenkeu (2018) 'Kemenkeu Terbitkan Kebijakan Tarif Cukai 2019'. Jakarta: Kementerian Keuangan.

Lutfi, M. and Baladina, N. (2018) 'Analisis Efisiensi Teknis Penggunaan Faktor Produksi Pertanian pada Usahatani Tembakau', Jurnal Ekonomi Pertanian dan Agribisnis (JEPA), 2(3), pp. 226-233.

Nazam, M., Suriadi, A. and Sahram (2014) 'Analisis Ekonomi Usaha Tani Tembakau Virginia dan Permasalahannya di Nusa Tenggara Barat (Kasus di Kabupaten Lombok Timur)', Semiloka Nasional Tanaman Pemanis,Serat, Tembakau, dan Minyak Industri Pusat Penelitian dan Pengembangan Perkebunan, pp. 179-188.

Nur, Y. H. and Salim, Z. (2014) 'Nilai the Competitiveness of Local Virginia Tobacco : a Value', Jurnal Ekonomi dan Pembangunan, 22, pp. 1-10.

Nyanga, P. H., Johnsen, F. H. and Aune, J. B. (2011) 'Smallholder farmers' perceptions of climate change and conservation agriculture: evidence from Zambia.', Journal of Sustainable Development, 4(4), pp. 73-85.

Pertiwi, S. and Prastya, A. (2020) 'Feasibility analysis of substituting gutters in NFT system network for horticulture production with corrugated roof sheet', IOP Conference Series: Earth and Environmental Science, 542(1). doi: 10.1088/1755-1315/542/1/012030.

Romli, M. S. et al. (2019) 'Model Pengendalian Supply (Penawaran) Tembakau Madura Pada Subsistem Hulu Sebagai Upaya Mendukung Penurunan Tingkat Konsumsi Rokok', Jurnal Hexagro, 3(2), pp. 39-45. doi: 10.36423/hexagro.v3i2.278.

Sari, R., Nofialdi and Putri, A. (2020) 'Financial feasibility of lime (citrus aurantifolia) farming in Tanah Datar District, West Sumatra', IOP Conference Series: Earth and Environmental Science, 583(1). doi: 10.1088/1755-1315/583/1/012016.

Septiadi, D. (2016) Dampak Kebijakan Perberasan Terhadap 
Pengentasan Kemiskinan Di Indonesia. Bogor: IPB.

Septiadi, D., Suparyana, P. K. and FR, A. F. U. (2020) 'Analisis pendapatan dan pengaruh penggunaan input produksi pada usahatani kedelai di kabupaten lombok tengah', JIA (Jurnal Ilmiah Agribisnis): Jurnal Agribisnis dan Ilmu Sosial Ekonomi PErtanian, 5(4), pp. 141-149.

Sudrajat, S. (2020) 'Kelayakan Usahatani Padi dan Pengaruhnya Terhadap Pendapatan Petani di Desa Margoluwih Kecamatan Seyegan', Majalah Geografi Indonesia, p. 53. doi: 10.22146/mgi.54500.

Sugiyono (2011) Metodologi Penelitian Kuantitatif, Kualitatif dan R\&D. Bandung: Alfabeta.

Suprihanti, A. et al. (2019) 'Dampak Kebijakan Cukai Rokok terhadap Distribusi Surplus Ekonomi Industri Rokok di Indonesia', Jurnal Agro Ekonomi, 37(1), pp. 1-23. doi: 10.21082/jae.v37n1.2019.1-23.

Wandita, D. T. (2020) 'Pengaruh Cukai Rokok Terhadap Konsumsi Rokok Serta Faktor-faktor Yang Mempengaruhi Konsumsi Rokok', Jurnal Pendidikan Ekonomi, 14(1), pp. 159-165. doi: 10.19184/jpe.v14i1.16659.

Wehantouw, A. D., Manginsela, E. P. and Moniaga, V. R. B. (2018) 'Faktor Beralihnya Tenaga Kerja Anak Petani Ke Sektor Non-Pertanian di Desa Treman Kecamatan Kauditan Kabupaten Minahasa Utara', AGRISOSIOEKONOMI, 14(2), p. $1 . \quad$ doi: 10.35791/agrsosek.14.2.2018.20098. 